\title{
Does the Eosinophil Have a Protective Role in Amebiasis?
}

\author{
Martha López-Osuna/ ${ }^{+}$, Juan R Velázquez*, Roberto R Kretschmer
}

\author{
Immunology Research Unit, Scientific Research, CMN-SXXI, IMSS, P.O.Box 73-032, México, D. F., 03020, \\ Mexico *Pulmonary Research Group, Department of Medicine, University of Alberta, Edmonton, \\ Alberta, Canada
}

While normal human eosinophils are destroyed in vitro by virulent Entamoeba histolytica, notwhistanding the presence of antibodies and complement, activated eosinophils promptly destroy the parasite although dying also at the end of the process. To study the possible in vivo participation of eosinophils in invasive amebiasis, we compared the induction of experimental amebic abscess of the liver (AAL) in gerbils (Meriones unguiculatus) previously made eosinophilic through Toxocara canis antigen injection and in normal control gerbils. After intraportal inoculation of $10^{5}$ ameba trophozoites (6 and $24 \mathrm{hr}$ ), the ratio of gerbils with AAL, as well as the number and size of the microabscesses was comparable in eosinophilic and control gerbils. However, at $96 \mathrm{hr}$ the number and size of the microabscesses were significanly smaller $(p<0.05)$ in eosinophilic gerbils. On the other hand the actuarial AAL survival curve up to 45 days post-amebic inoculation was signficantly $(p<0.05)$ shifted to the right in controls. These results suggest that antigen-induced eosinophilia may exert a protective effect against $A A L$ in gerbils.

Key words: eosinophilia - Entamoeba histolytica - amebic abscess of the liver - gerbils

Amebiasis is a major health problem in developing countries. Entamoeba histolytica infects $5 \mathrm{x}$ $10^{8}$ people worldwide, more than $90 \%$ of them living in West and South East Africa, China, SE Asia, México, the western portion of South America and India (Smyth 1994). Only 10\% of all infected individuals eventually develop invasive amebiasis ranging from mild (i.e. self-limited) or serious intestinal amebiasis, to life-threatening hepatic invasion (Walsh 1986).

It has been suggested that there are in fact two different species of Entamoeba. One, the classic pathogenic E. histolytica discovered by Schaudinn in 1903. The other, the non-pathogenic E. dispar described by Brumpt in 1925, based mainly on epidemiological considerations. The concept of two Entamoeba species began to be objectively established by functional in vitro studies (MartínezPalomo 1982, Mirelman \& Chayen 1990) and zymodeme patterns (Sargeaunt 1988), culminating now with molecular genetic data (Tannich \& Burchard 1991, Tannich 1996).

Thus, the majority of ameba infected individuals may actually harbour $E$. dispar, leaving the $E$.

\footnotetext{
This work was supported by a grant PCSABNA 0211552 from the National Council of Science and Technology of México (CONACYT).

${ }^{+}$Corresponding author. Fax:

Received 3 September 1997

Accepted 30 September 1997
}

histolytica as the agent of the relatively rare invasive intestinal and extraintestinal disease. Amebic abscess of the liver (AAL) on the other hand, occurs in less than $1 \%$ of individuals with invasive intestinal amebiasis (Martínez-Palomo et al. 1993).

Why the vast majority of individuals ( $\geq 99 \%)$ appear to be resistant to extraintestinal invasion remains unknown but some inroads have now been made: a significant increase in the SCO1 complotype and in HLA-DR3 was found in 160 Mexican mestizos (adults and children) with AAL when compared to healthy controls, to adult patients with amebic rectocolitis or to asymptomatic amebic carriers (Arellano et al. 1996). DNA subtyping is now in process to confirm these findings.

Studies of human amebiasis and of experimental animal models of amebic disease have suggested that cell-mediated rather than humoral immune mechanisms, are responsible for acquired immunity to AAL (De León 1970, Salata \& Radvin 1986, Kretschmer \& López-Osuna 1990). Moreover, axenically grown trophozoites of E. histolytica kill in vitro normal human neutrophils and eosinophils (not-withstanding the aid by antibody and complement), normal monocytes and lymphocytes, without suffering changes in their own viability (Jarumilinta \& Kradolfer 1964, Artigas et al. 1966, Guerrant et al. 1981, Salata et al. 1985, 1987, López-Osuna et al. 1986, López-Osuna \& Kretschmer 1989). However, if macrophages are activated beforehand, they become capable of ef- 
fectively destroying virulent amebas, even though finally succumbing in the process as well (Salata et al. 1985). In our laboratory we found that the same occurs with activated human peripheral blood eosinophils (López-Osuna et al. 1992).

There is no circulating eosinophilia in most protozoan infections, yet this is not necessarily an argument against their possible participation in AAL, specially because eosinophils are regularly found in the early inflammatory stages of experimental amebic liver disease (Tsutsumi et al. 1984), and since the bulk of eosinophils in the body normally dwells, not intravascularly but in tissues (Weller 1991). We therefore decided to study in vivo the role of eosinophils, by inducing eosinophilia in gerbils ( $M$. unguiculatus) through four injections of an innocuous Toxocara canis antigen, prior to the induction of experimental AAL with 1 x $10^{5}$ intraportally injected ameba trophozoites (Velázquez et al. 1995, López-Osuna 1995, Velázquez 1996). This relatively small inoculum of amebas (compared to the usual $1 \times 10^{6}$ ) was chosen in order to maximize the eosinophil's chances to reveal its eventual protective role against E. histolytica. Gerbils reached their eosinophilia peak at 21 days (after the first injection of the antigen) (Fig.1 and Table) at which time they and their controls (i.e.normal eosinophil number) received the intraportal injection of E. histolytica HM1IMSS in saline. Animals were then sacrificed at 6, $24,96 \mathrm{hr}$ and - those surviving - at 45 days postinoculation.

The livers revealed comparable histopathologic amebic lesions at 6 and $24 \mathrm{hr}$ in both groups. At 96 $\mathrm{hr}$, however, microabscesses were significantly fewer and smaller in the eosinophilic group $(\mathrm{p}<0.05)$ (Fig. 2). In the 45 days actuarial AAL curves, eosinophilic gerbils revealed a better survival rate and had fewer abscesses than their normal controls ( $\mathrm{p}<0.05)$ (Fig.3).

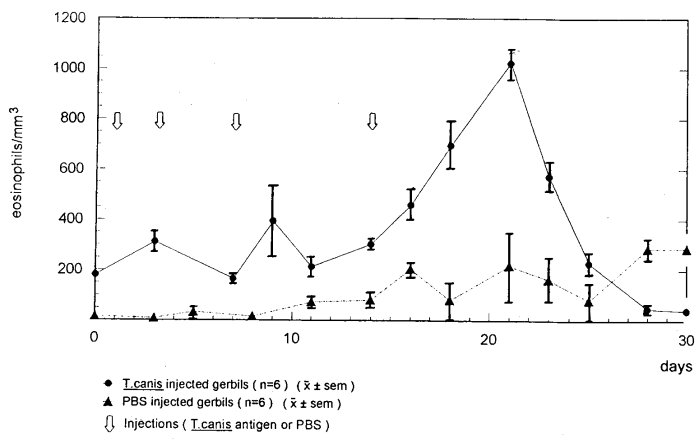

Fig. 1: eosinophilia in Toxocara canis injected gerbils $(n=6)$. Circulating blood eosinophils in T. canis antigen ( ) and PBS ( ) injected $(\downarrow)$ gerbils over a 30 -day period. Mean \pm SEM. At day $21(\mathrm{p}<0.02)$.

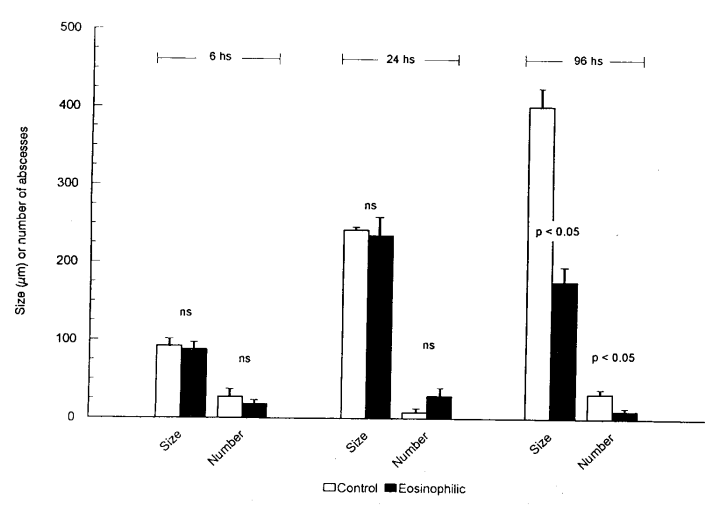

Fig. 2: size (mm) and number of microabscesses per liver found in experimental (dark columns) and control (light columns) gerbils. At $96 \mathrm{hr}$ the eosinophilic gerbils revealed fewer and smaller microabscesses than the controls $(\mathrm{p}<0.05)$.

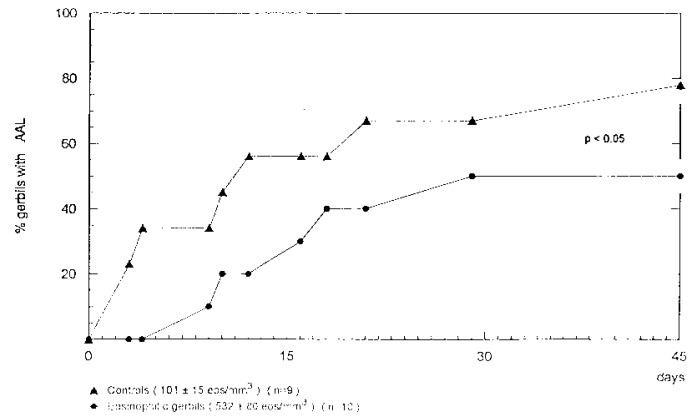

Fig. 3: actuarial curve of eosinophilic gerbils with AAL. Cumulative percent of eosinophilic ( ) and control ( ) gerbils dying spontaneously with ambic abscess of the liver within 45 days.

Serum IL-5 levels (ELISA Endogen test) were measured during these experiments but no significant changes were observed at the chosen times (Table).

In order to confirm these findings, we are now studying AAL in eosinopenic gerbils. A search is also presently under way for specific eosinophil granule proteins (MBP, ECP, EPO) in the livers of eosinophilic gerbils in order to ascertain the true presence or absence of this leucocyte (Gleich et al. 1994). Much remains to be learned in order to establish if eosinophils actually play a role in invasive amebiasis. Screening carefully those gerbils that escape (or recover) from the formation of amebic abscesses (rather than studying only those with AAL) appears now to be mandatory. The traditionally eschewed subject of active participation of eosinophils in protozoan diseases (trypanosomiasis, malaria and leishmaniasis) has become an important landmark in today's immunoparasitology. Invasive amebiasis could apparently join this group. 
TABLE

Circulating blood eosinophil counts and serum IL-5 levels in eosinophilic and control gerbils just before 6, 24, 96 $\mathrm{hr}$ and 45 days post-amebic inoculation

\begin{tabular}{|c|c|c|c|c|c|c|}
\hline & & $\underset{(0 \mathrm{hs})}{\text { Baseline }}$ & $6 \mathrm{hs}$ & 24 hs & 96 hs & 45 days \\
\hline Controls & $\begin{array}{l}\operatorname{Eos}^{x} \\
\text { IL-5 }^{\circ}\end{array}$ & $\begin{array}{c}101 \pm 15 \\
22 \pm 1\end{array}$ & $\begin{array}{c}4 \\
46 \pm 13\end{array}$ & $\begin{array}{c}- \\
25 \pm 0\end{array}$ & $\begin{array}{l}59 \pm 21 \\
35 \pm 14\end{array}$ & $\begin{array}{c}103 \pm 42 \\
65 \pm 6\end{array}$ \\
\hline \multicolumn{2}{|l|}{$n$} & $38(5)^{4}$ & 13 & 8 & 8 & $9(2)^{*}$ \\
\hline Eosinophilic & $\begin{array}{l}\text { Eos } \\
\text { IL-5 }\end{array}$ & $\begin{array}{c}532 \pm 80 \\
29 \pm 4\end{array}$ & $\begin{array}{c}- \\
51 \pm 18\end{array}$ & $\begin{array}{c}- \\
63 \pm 30\end{array}$ & $\begin{array}{l}64 \pm 19 \\
35 \pm 10\end{array}$ & $\begin{array}{l}63 \pm 32 \\
78 \pm 19\end{array}$ \\
\hline \multicolumn{2}{|l|}{$n$} & $38(5)^{4}$ & 11 & 8 & 9 & $10(5)^{=}$ \\
\hline
\end{tabular}

\footnotetext{
${ }^{x}$ Eosinophils/mm $\mathrm{mm}^{3}(\bar{x} \pm \mathrm{sem})$

- IL-5, $\mathrm{pg} / \mathrm{ml}$ ( $\bar{x} \pm \mathrm{sem}$ ) ( normal range in non experimentally manipulated gerbils; $39 \pm 7 \mathrm{pg} / \mathrm{ml}, n=10$ )

$\triangle$ Number in brackets $=$ IL-5 determination

- Number in brackets $=$ gerbils sacrificed at $\mathbf{4 5}$ days
}

\section{ACKNOWLEDGMENTS}

To Archives of Medical Research (Vol. 26 p. S9396, 1995) for authorization to use Figures and Table.

\section{REFERENCES}

Arellano J, Pérez-Rodríguez M, López-Osuna M, Velázquez JR, Granados J, Justiniani N, Santos JI, Madrazo A, Muñoz L, Kretschmer R 1996. Increased frequency of HLA-DR3 and complotypes SCO1 in Mexican mestizo children with amoebic abscess of the liver. Parasite Immunol 18: in press.

Artigas J, Otto I, Kawada ME 1966. Acción de Entamoeba histolytica sobre leucocitos PMN humanos vivos. Bol Chil Parasitol 21: 114-118.

Brumpt E 1925. Étude sommaire de 1' Entamoeba dispar' n.s.p. Amibe à kystes quadrinucléés, parasite de l'homme. Bull Acad Med (Paris) 94: 943952.

De León A 1970. Pronóstico tardío en el absceso hepático amibiano. Arch Invest Med (Méx )1: S205-S206 .

Gleich GJ, Glitz DG, Abu-Ghazaleh RI 1994. Eosinophil granule proteins: structure and function, p.120. In GJ Gleich \& AB Kay, (eds) Eosinophils in Allergy and Inflammation. Marcel Dekker, New York.

Guerrant RL, Brush J, Ravdin JI, Sullivan JA, Mandell GL 1981. Interaction between Entamoeba histolytica and human PMN neutrophils. J Infect Dis 143: 8393.

Jarumilinta R, Kradolfer F 1964. The toxic effect of Entamoeba histolytica on leukocytes. Ann Trop Med Parasitol 58: 375-381.

Kretschmer RR, López-Osuna M 1990. Effector mechanisms and immunity to amebas, p. 105-122. In RR Kretschmer, Amebiasis: Infection and Disease by Entamoeba histolytica. CRC Press, Boca Ratón, Fl, U.S.A.

López-Osuna M 1995. Interacción de eosinófilos y En- tamoeba histolytica. $\mathrm{PhD}$ Thesis, $139 \mathrm{pp}$.

López-Osuna M, Kretschmer RR 1989. Destruction of normal eosinophils by Entamoeba histolytica. Parasite Immunol 11: 403-411.

López-Osuna M, Arellano J, Kretschmer RR 1992. The destruction of virulent Entamoeba histolytica by activated human eosinophils. Arch Med Res (Méx) 23: 143-145.

López-Osuna M, Contreras BA, Kretschmer R 1986. In vitro interaction of PMN leucocytes and Entamoeba histolytica. Arch Invest Med (Méx) 17: 247-249.

Martínez-Palomo A 1982. The Biology of Entamoeba histolytica. Research Studies Press, John Wiley \& Sons Ltd., Chichester, 161 pp.

Martínez-Palomo A, Kretschmer R, Meza-GPI 1993. Entamoeba histolytica and amoebiasis, p.143-156. In KS Warren, Immunology and Molecular Biology of Parasitic Infections. Blackwell Science Ltd., Oxford.

Mirelman D, Chayen A 1990. Interaction of amebas with cells, p. 160-172. In RR Kretschmer, Amebiasis: Infection and disease by Entamoeba histolytica. CRC Press Boca Raton, Fl, U.S.A.

Salata RA, Ravdin JI 1986. Review of the human immune mechanisms directed against Entamoeba histolytica. Rev Infect Dis 8: 261-272.

Salata RA, Cox J, Ravdin JI 1987. The interaction of human T-lymphocytes and Entamoeba histolytica: killing of virulent amoeba by lectin-dependent lymphocytes. Parasite Immunol 9: 249-261.

Salata RA, Pearson RD, Ravdin JI 1985. Interaction of human leucocytes and Entamoeba histolytica. Killing of virulent amebae by activated macrophage. $J$ Clin Invest 76: 491-499.

Sargeaunt PG 1988. Zymodemes of Entamoeba histolytica, p. 370-387. In JI Ravdin, Amebiasis: Human infection by Entamoeba histolytica. J Wiley \& Sons, New York.

Schaudinn F 1903. Untersuchungen über die 
Fortpflanzung einiger Rhizopoden. Arb Kaiserl Ges 19: 547.

Smyth JD 1994. The amoebae, p. 24-43. In JD Smyth, Introduction to animal parasitology. Cambridge University Press, Cambridge.

Tannich E 1996. Recent advances in DNA-mediated gene transfer of Entamoeba histolytica. Parasitol Today 12: 198-200.

Tannich E, Burchard GD 1991. Differentiation of pathogenic from nonpathogenic Entamoeba histolytica by restriction fragment analysis of a single gene amplified in vitro. J Clin Microb 29: 250-255.

Tsutsumi V, Mena López R, Anaya-Velázquez F, Martínez-Palomo A 1984. Cellular basis of experi- mental amebic liver abscess formation. Am J Pathol 117: 81-91.

Velázquez JR 1996. La eosinofilia en el absceso hepático experimental. M.Sc. Thesis, 88 pp.

Velázquez JR, Llaguno P, Fernández-Díez J, Pérez M, Arellano J, Kretschmer RR 1995. Antigen induced eosinophilia protects gerbils (M.unguiculatus)against experimental amebic abscess of the liver. Arch Med Res 26: S93-S98.

Walsh JA 1986. Problems in recognition and diagnosis of amebiasis:estimation of the global magnitude of morbidity and mortality. Rev Infect Dis 8: 228-238.

Weller PF 1991. The immunobiology of eosinophils. NEJM 324: 1110-1118. 